Diabetologia, Suppl. to $9,356-363(1973)$

(C) Sy Springer-Verlag 1973

\title{
Clinical Experience with Glipizide in the Treatment of Mostly Complicated Diabetes
}

\author{
A. Masbernard, C. Giudicelli and. J. Massey \\ Hôpital d'Instruction des Armées du Val-de Grâce, Paris, France \\ Received: April 10, 1973, and in revised form: June 15, 1973, accepted: June 27, 1973
}

Summary. Thirty-five diabetic patients (mean age 60) underwent regularly controlled treatment for an average of 7 months with $21 / 2$ to $20 \mathrm{mg}$ of glipizide daily, the mean dose being almost $10 \mathrm{mg} /$ daily. These patients had been diabetics for an average of 9 years, most had been previously treated with other sulphonamides, one third were obese and $90 \%$ had degenerative complications and/or an associated disease. Results showed a $23 \%$ mean decrease in mean blood sugar levels and a $21 \%$ decrease in maximal blood sugar levels during the day. There was an increase in the number of well or very well controlled patients and a decrease of non-satisfactory results. Renal, hepatic and haematologic monitoring reveared no abnormalities. Minor hypoglycaemic manifestations were not uncom- mon. Two severe hypoglycaemic attacks occurred in older patients with renal insufficiency associated with hepatic dysfunction. Glipizide is contra-indicated when kidney function is reduced by more than $3 / 4$ and additional caution seems to be necessary in the event of associated hepatic damage. The drug appears to enhance the antiprothrombin action of anticoagulants.

Key words: Anticoagulants, clinical use of sulfonylureas in diabetes, maturity onset diabetes, glipizide, hypoglycaemia, hypoglycaemic sulphonamides, oral antidiabetic substances, renal insufficiency, sulfonylureas, transaminases, triglycerides.
Among the numerous aminoethylphenylsulfonylureas synthesized in Italy by Ambrogi et al. $[1$, 2], N-(4-(B-(5-methylpyrazine-2-carboxamido)-ethyl)benzenesulfonyl)- $\mathrm{N}$-cyclohexylurea (approved name, glipizide) has been shown to possess extremely potent hypoglycaemic properties. These properties have been the object of precise pharmacological research [3] in the Department of Pharmacology at the Carlo Erba Therapeutic Research Institute in Milan. These studies showed that glipizide exerts an antagonist action on hyperglycaemia following glucose loading, lowers the blood sugar level in healthy animals and increases insulinaemia by sensitizing pancreatic betacells to the physiological glucose stimulus. The dose necessary is more than one hundred times lower than that of other sulphonylureas studied comparatively (tolbutamide and glycyclamide).

The chemical structure of glipizide is close to that of glibenclamide. Its potent action, which makes it an antidiabetic sulphonamide of the "second generation", as well as the characteristies of its action [14] and its lack of toxicity have inspired its trial in clinical medicine. The first results of such trials were reported by Pedrazzi et al. [19], Parodi [18] and Greeo et al. [8].

These trials, which involved a total of $134 \mathrm{pa}$ tients, confirmed the potent therapeutic action of glipizide, which was equivalent and sometimes superior to that of glibenclamide in maturity onset diabetes in daily doses of 5 to $20 \mathrm{mg}$ administered for periods up to a year and a half [18]. Good toleration of the drug was also confirmed. For the past year, we have been able to try this new antidiabetic in 35 patients, either in hospital or as out-patients, who were followed for an average of 7 months.

\section{Patient Population}

Clinical data concerning the 35 non-insulin dependent diabetic patients are summarized in Table 1.

Only seven patients had been diabetic for less than 5 years; 13 had had diabetes for more than 10 years.

Only four patients were free of any associated disorder or degenerative complications. The fact that these cases of diabetes were relatively longstanding accounts for the fairly high incidence of degenerative complications.

It should be pointed out that this population of mainly elderly and long standing diabetic patients was a high risk group for the use of a high potency oral hypoglycaemic agent; the use of such agents could conceivably be hazardous in severe cases of this type.

Thirty-three of the thirty-five patients had been previously treated; fo ronly two patients was glipizide the first antidiabetic treatment undertaken. In two cases only, previous treatment was with insulin, which was later discontinued; in the other cases it was one or two oral antidiabetics, a sulphonamide alone in 13 cases (glybutamide 1, chlorpropamide 2, glycodiazine 3, glibenclamide 1, glisoxepide 7), a combination of one of these sulphonamides with a biguanide in 15 eases (usually phenformin) and a biguanide alone in 2 cases.

\section{Management and Supervision of Treatment}

Treatment with glipizide was begun in 35 patients, of whom 28 were out-patients at the beginning 
of therapy. These patients were periodically assessed at intervals of 1 to 2 months. Each time the following parameters of therapeutic efficacy were measured in addition to weight and any possible manifestations of hypoglycaemia or intolerance: blood sugar level after breakfast, before and $2 \mathrm{~h}$ after the midday meal, before and $1 \frac{1}{2}$ or $2 \mathrm{~h}$ after the evening meal and sometimes at midnight (titration by the Auto-Analyzer method with reduction of ferricyanide); twenty-four hour glycosuria; acetonuria; cholesterolaemia (AutoAnalyzer method, Pearson); lipidaemia (nephelometric method using dextran sulfate in the AutoAnalyzer); blood triglyceride levels (auto-analyzer fluorimetric method). In addition possible toxic effects were monitored by measuring proteinuria; sulphonamide previously used. In only one case, a biguanide had to be added to glipizide during the 6 th month of treatment because of insufficient control by the latter drug.

Dosage changes of glipizide were cautious and gradual, in view of the proven potency of its hypoglycaemic action. As a general rule, treatment was begun with one tablet containing $5 \mathrm{mg}$ of glipizide as a replacement for $4 \mathrm{mg}$ of glibenclamide, or $7 \frac{1}{2} \mathrm{mg}$ of glisoxepide, or $750 \mathrm{mg}$ of glycodiazine, or $500 \mathrm{mg}$ of chlorpropamide, or $1000 \mathrm{mg}$ of glybutamide.

This initial quantity, which was administered in one or two doses, depending on the case, was then adjusted, according to the results obtained, or maintained unchanged, or gradually increased. From the

Table 1. Clinical data of the treated patients

\begin{tabular}{|c|c|c|}
\hline \multicolumn{3}{|l|}{$\left.\begin{array}{l}\text { Male } 29 \\
\text { Female } 6\end{array}\right\} 35$ patients } \\
\hline \multicolumn{3}{|l|}{ Age $34-82$ years, mean age 60 years } \\
\hline \multicolumn{3}{|c|}{$\begin{array}{ll}\text { Family history of diabetes } & 30 \% \\
\text { Obesity ( }>\text { due body weight }+10 \%) & 30 \%\end{array}$} \\
\hline \multicolumn{3}{|c|}{ Diabetes known and/or treated since 9 years on average } \\
\hline Associated pathological conditions: & $\begin{array}{l}\text { gout } \\
\text { chronic alcoholism } \\
\text { liver cirrhosis } \\
\text { active chronic hepatitis } \\
\text { biliary lithiasis } \\
\text { haemochromatosis } \\
\text { asthma } \\
\text { chronic pancreatitis } \\
\text { rheumatoid arthritis } \\
\text { chronic lymphoid leukemia }\end{array}$ & each 1 \\
\hline Degenerative complications of diabe & $\begin{array}{l}\text { arteritis of the lower limbs. } \\
\text { peripheral neuropathy } \\
\text { coronary artery disease } \\
\text { diabetic retinitis } \\
\text { cataracts } \\
\text { urinary infection } \\
\text { renal insufficiency } \\
\text { lung/skin infections }\end{array}$ & $\begin{array}{r}16 \\
11 \\
11 \\
11 \\
3 \\
8 \\
8 \\
5\end{array}$ \\
\hline
\end{tabular}

urine cytology; blood urea (diacetylmonoxime method); blood uric acid levels (phosphotungstic reagent, Auto-Analyzer method); glutamic oxalacetic and glutamic pyruvic transaminases (U.V. absorption method); alkaline phosphatases (Bodanski's method); fibrinogen (ponderal method); red blood count, platelet and white cell counts including differential count.

Throughout the entire duration of treatment, the diet which had been adapted to the patient's usual requirements and to his weight and usually contained $180 \mathrm{~g}$ of carbohydrates daily, was not changed, but it should be noted that this diet was not always strictly followed by patients at home.

In all cases where the patient was on a biguanide before the beginning of treatment with glipizide, the former was maintained at the same dose during the trial so as to enable a valid comparison with the first to the eighth month of treatment, mean doses successively worked out at $5.90 \mathrm{mg}, 6.16 \mathrm{mg}, 7.05 \mathrm{mg}$, $8.6 \mathrm{mg}, 8.75 \mathrm{mg}, 9.15 \mathrm{mg}, 9.40 \mathrm{mg}$ and $9.60 \mathrm{mg}$ daily. In some cases the daily dose was kept down to as little as $21 / 2 \mathrm{mg}$ while in others it had to be increased. to $20 \mathrm{mg}$ daily (in two cases and only after 3 months of treatment). Duration of treatment varied from 15 days to 10 months with a mean of 7 months; duration exceeded 6 months in 27 cases.

\section{Results}

\section{Carbohydrate Metabolism}

1a) Daily glycosuria cannot be considered representative of correct equilibrium of treated diabetes and of its course, especially in these relatively aged patients who have been diabetics for a considerable time. 
16) No lasting acetonuria and no drop in alkaline reserve occurred.

1c) Blood sugar levels were used to assess therapeutic activity. The mean blood sugar level on the day before glipizide therapy was begun, was 163 $\mathrm{mg} / 100 \mathrm{ml}$ and the maximum blood sugar level averaged $211 \mathrm{mg} / 100 \mathrm{ml}$ (Fig. 1). If we consider the following as criteria for correctly balanced diabetes blood sugar levels rose from 126 to $152 \mathrm{mg} / 100 \mathrm{ml}$ and maximal blood sugar levels from 167 to $200 \mathrm{mg} / 100 \mathrm{ml}$ on average, while the percentage of very good diabetic control dropped from 46 to $31 \%$ and that of poor results rose from 16 to $30 \%$ ). However, this course was due to seven patients in whom dosage had to be increased to overcome this partial and transient "escape" from the action of the sulphonamide, which very good

good

fairly good

poor

$$
\begin{array}{ll}
\text { mean blood sugar level } & \leq 120 \mathrm{mg} / 100 \mathrm{ml} \\
\text { maximum blood sugar level } & \leq 160 \mathrm{mg} / 100 \mathrm{ml} \\
\text { mean blood sugar level } & \leq 140 \mathrm{mg} / 100 \mathrm{ml} \\
\text { maximum blood sugar level } & \leq 180 \mathrm{mg} / 100 \mathrm{ml} \\
\text { mean blood sugar level } & \leq 160 \mathrm{mg} / 100 \mathrm{ml} \\
\text { maximum blood sugar level } \leq 200 \mathrm{mg} / 100 \mathrm{ml} & \leq 160 \mathrm{mg} / 100 \mathrm{ml} \\
\text { mean blood sugar level } & >1600 \mathrm{mg} / 100 \mathrm{ml}
\end{array}
$$

our patients could be divided up into the following categories prior to glipizide therapy

$$
\begin{aligned}
4 \text { very good } & =11 \% \\
11 \text { good } & =32 \% \\
6 \text { fairly good } & =17 \% \\
14 \text { poor } & =40 \%
\end{aligned}
$$

On glipizide, the course of mean and maximal blood sugar levels showed gradual improvement during the first five months of treatment with an average drop in mean blood sugar level from 163 to $126 \mathrm{mg} / 100 \mathrm{ml}(-23 \%)$ and in maximal blood sugar level from 211 to $167 \mathrm{mg} / 100 \mathrm{ml}(-21 \%$ ) (Fig. 1). The quality of the diabetic control thus obtained with glipizide was also improved (Table 2), with an increase of very good results from 11 to $46 \%$, and an increase of very good and good results from 43 to $54 \%$. The percentage of poor results dropped from 40 to $16 \%$ during the second trimester of treatment.

Between the 6 th and the 8 th months of treatment, results obtained with glipizide were not as good (mean

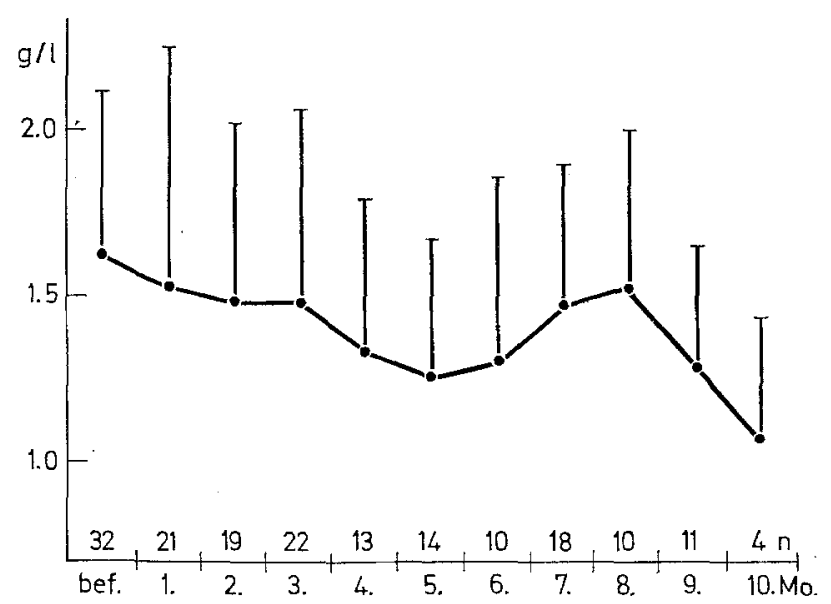

Fig. 1. Course of mean and maximal blood sugar levels during treatment of thirty-five diabetic patients with glipizide ( $n=$ number of patients controlled every month) could possibly be due to less rigid dietary adherence as the trial progressed.

After the 8th month, following this dosage "readjustment", results were once again better, although admittedly in a smaller number of patients. Mean blood sugar levels dropped from 152 to 129 at the 9 th month and to $107 \mathrm{mg} / 100 \mathrm{ml}$ at the 10 th month and maximal blood sugar levels dropped from 200 to 165 and to $144 \mathrm{mg} / 100 \mathrm{ml}$ on average.

Comparison of glipizide with the sulphonamide previously used showed that patients on glipizide felt better in 11 cases, the same in 19 cases and only one patient felt worse.

In the course of treatment, patient's weights showed no appreciable sustained variation. There was a slight increase in half the cases, weight was stable in $25 \%$ of cases and decreased slightly in $25 \%$ of cases. Mean weight was $70.0 \mathrm{~kg}$ at the beginning of treatment, and $70.6 \mathrm{~kg}$ at the end of treatment with glipizide.

Comparison of glipizide's activity with that of the sulphonamides for which it was substituted showed that $5 \mathrm{mg}$ of glipizide were approximately equivalent to $4 \mathrm{mg}$ of glibenclamide or to 9 or $10 \mathrm{mg}$ of glisoxepide. The number of patients previously treated with glycodiazine, chlorpropamide or glybutamide was too small to enable determination of precise weight-activity correlations.

Glipizide may thus be considered an antidiabetic sulphonamide of certain and sustained clinical efficacy, which is capable of markedly improving the therapeutic results previously obtained with other sulphonamides.

\section{Lipid Metabolism}

Glipizide did not exert any appreciable effect on lipid metabolism, which indirectly reflects diabetic equilibrium. It should be borne in mind, however, that in the immense majority of cases sulphonamide or mixed therapy had been previously administered and could have corrected any major disturbances of lipid metabolism. 
2a) Cholesterolaemia, which was initially between 165 and $340 \mathrm{mg} / 100 \mathrm{ml}$ (mean value $227 \mathrm{mg} / 100 \mathrm{ml}$ ), underwent non-homogeneous variations around the mean level calculated under treatment (129 observations) at $235 \mathrm{mg} / 100 \mathrm{ml}$.

2b) In the same way, lipidaemia, the mean value of which was initially $738 \mathrm{mg} / 100 \mathrm{ml}$, showed small and non-homogeneous variations around the mean value during treatment with glipizide, calculated at $714 \mathrm{mg} / 100 \mathrm{ml}$ (128 observations). in the morning after a dose of $21 / 2 \mathrm{mg}$ ( 2 cases) or $5 \mathrm{mg}$ ( 5 cases) of glipizide at breakfast, or around 4 o'clock in the afternoon after absorption of $10 \mathrm{mg}$ at midday (1 case). Proof of the hypoglycaemic nature of these symptoms was rarely obtained through the determinations performed. However, there is no doubt as to its authenticity. In only one case, these symptoms were of late onset, occurring during the 6 th month of treatment after an increase in dosage. None of the patients who exhibited such manifestations had

Table 2. Comparative therapeutic results obtained with other sulfonamides and with glipizide during the first three months and during the second and third trimesters of treatment in 35 controlled patients

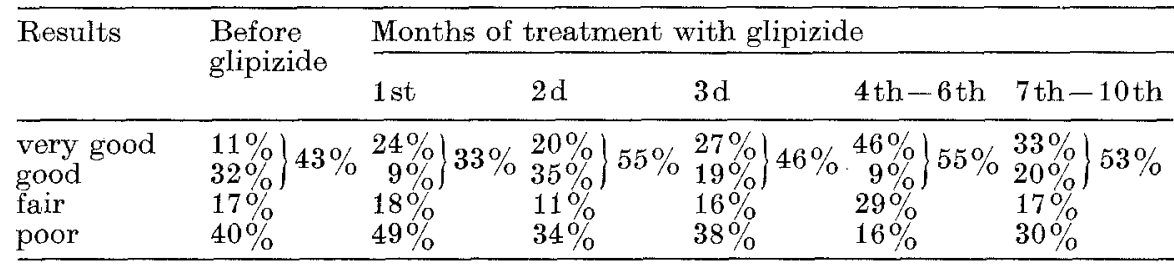

Table 3. Lipid levels during glipizide treatment

\begin{tabular}{|c|c|c|c|c|c|c|}
\hline \multirow[t]{2}{*}{ Blood levels } & \multicolumn{3}{|c|}{ Before glipizide } & \multicolumn{3}{|c|}{ During glipizide treatment } \\
\hline & $\begin{array}{l}\text { extreme } \\
\text { values }\end{array}$ & $\begin{array}{l}\text { mean } \\
\text { value }\end{array}$ & $\begin{array}{l}\text { number of } \\
\text { determina- } \\
\text { tions }\end{array}$ & $\begin{array}{l}\text { extreme } \\
\text { values }\end{array}$ & $\begin{array}{l}\text { mean } \\
\text { value }\end{array}$ & $\begin{array}{l}\text { number of } \\
\text { determina- } \\
\text { tions }\end{array}$ \\
\hline Cholesterol & & & & & & \\
\hline $\mathrm{mg} / 100 \mathrm{ml}$ & $165-340$ & 227 & 31 & $155-330$ & 235 & 129 \\
\hline $\mathrm{mg} / 100 \mathrm{ml}$ & $500-1360$ & 738 & 28 & $380-1200$ & 714 & 128 \\
\hline $\begin{array}{l}\text { Triglycerides } \\
\text { mg } / 100 \mathrm{ml}\end{array}$ & $60-350$ & 121 & 18 & $50-285$ & 89 & 107 \\
\hline
\end{tabular}

2c) On the other hand, blood triglycerides, which were initially between 60 and $350 \mathrm{mg} / 100 \mathrm{ml}$ (mean 121) exhibited a marked tendency to decrease and oscillated around the mean value of $89 \mathrm{mg} / 100 \mathrm{ml}$ (107 observations) during treatment. This difference of $32 \mathrm{mg} / 100 \mathrm{ml}$ is, however, not statistically significant $(p>0.05)$.

\section{Incidents and Accidents of Treatment}

3a) Minor hypoglycaemic manifestations were observed in 9 patients $(26 \%)$ in spite of the care taken with the dose administered. It has to be noted, however, that these slight symptoms were most probably associated with the low caloric content of the usual French breakfast. This interpretation is supported by the fact that these manifestations were usually overcome by administering the drug in two doses or by increasing the carbohydrate content of the previous meal at the expense of the two others. In most cases they were observed during the first month of treatment and were expressed in the form of hunger and weakness with no other major symptoms of hypoglycaemia. These symptoms occurred around 11 o'clock functional renal insufficiency. The same is not true for major attacks.

3b) A major hypoglycaemic attack made discontinuation of therapy obligatory after two and a half months of treatment with $10 \mathrm{mg}$ daily in a 65 year old patient who had had diabetes for 23 years and whose renal insufficiency (blood urea $34 \mathrm{mg} / 100 \mathrm{ml}$, blood creatinine $1.4 \mathrm{mg} / 100 \mathrm{ml}$, urea clearance 24 $\mathrm{ml} / \mathrm{min}$, endogenous creatinine clearance $43 \mathrm{ml} / \mathrm{min}$, P.A.H. clearance $112 \mathrm{ml} / \mathrm{mn}$ ) and hepatic (increased transaminases) insufficiency should have contra-indicated the use of a sulphonylurea.

3c) Two patients died from a myocardial infarction during the observation period. Their ages were 71 and 72 years respectively.

The first occurred despite the correction of a hypoglycaemic coma after 20 days of treatment with only $5 \mathrm{mg}$ glipizide daily in this patient whose renal insufficiency (endogenous creatinine clearance $25 \mathrm{ml} /$ $\mathrm{mn}$ ) and hepatic cirrhosis (SGOT 75 U., Alk. phosph. 10.5 Bod. U.) should have been a mandatory contraindication.

The second case occurred during the 7th month of treatment with glipizide in a 72 year old patient 
with arteritis, long-standing coronary artery disease and nephrosclerosis, with a blood urea of $60 \mathrm{mg} / 100 \mathrm{ml}$. With $71 / 2 \mathrm{mg}$ daily, satisfactory equilibrium had been obtained for 6 months. When this equilibrium was broken, dosage was increased to $10 \mathrm{mg}$ daily in two doses and four days later the patient suffered an extensive myocardial infarction. There were no apparent manifestations of hypoglycaemia preceding the coronary accident and not once did the routine tests reveal hypoglycaemia.

\section{Toleration and Toxicity}

4a) None of the thirty-five patients treated had any functional symptoms, in particular gastrointestinal, nor any objective signs (skin allergy) suggesting intolerance to the drug. No antabuse-like effect was noted.

4b) Renal function:

A. There was no new onset of proteinuria nor were any abnormal urinary cytologic elements observed; when these abnormalities pre-existed, there was no aggravation.
A. The initial mean number of red blood cells $\left(4354000 / \mathrm{mm}^{3}\right)$ did not undergo any marked variations except for a frequent tendency to increase, with a mean "treatment" value of $4556000 / \mathrm{mm}^{3} \quad(123$ counts).

B. There was no depression of platelets by glipizide (103 counts), even in a case of thrombocytopenia due to splenic hyperactivity in a cirrhotic patient. In this case the initial count was $205000 / \mathrm{mm}^{3}$ and under treatment this value was maintained at $210000 / \mathrm{mm}^{3}$.

Platelets showed a tendency to increase during the first four months of treatment to around $230000 /$ $\mathrm{mm}^{3}$ on average. This tendency later disappeared $\left(200000 / \mathrm{mm}^{3}\right.$ on average after the 5 th month).

C. Examination of leukocytes and granulocytes did not demonstrate any toxic action of glipizide on white blood cells. The initial mean values of leukocytes and neutrophilic granulocytes before treatment were 6275 and $4170 / \mathrm{mm}^{3}$ respectively. White blood cell counts in 112 patients under treatment showed mean values of 6760 and $4300 / \mathrm{mm}^{3}$ for leukocytes and neutrophilic granulocytes respectively. There was a

Table 4. Biological toxicity-control determinations

\begin{tabular}{|c|c|c|c|c|c|c|}
\hline & \multicolumn{3}{|l|}{ Before glipizide } & \multicolumn{3}{|c|}{ Under glipizide treatment } \\
\hline & Extreme values & Mean value & $\begin{array}{l}\text { Number of } \\
\text { determinat. }\end{array}$ & Extreme values & Mean value & $\begin{array}{l}\text { Number of } \\
\text { determinat. }\end{array}$ \\
\hline $\begin{array}{l}\text { Blood urea } \\
\mathrm{mg} / 100 \mathrm{ml}\end{array}$ & $18-70$ & 40.6 & 32 & $15-75$ & 41 & 138 \\
\hline $\begin{array}{l}\text { Serum uric acid } \\
\mathrm{mg} / 100 \mathrm{ml}\end{array}$ & $3.4-9.0$ & 5.46 & 28 & $3.2-12.0$ & 6.04 & 127 \\
\hline Erythrocytes $/ \mathrm{mm}^{3}$ & $3300000-5400000$ & 4354000 & 27 & $3150000-5800000$ & 4566000 & 123 \\
\hline Platelets $/ \mathrm{mm}^{3}$ & $120000-300000$ & 205000 & 26 & $116000-350000$ & 210000 & 103 \\
\hline Leucocytes/mm ${ }^{3}$ & $4100-10400$ & 6275 & 27 & $3100-12000$ & 6760 & 112 \\
\hline Granulocytes $/ \mathrm{mm}^{3}$ & $2360-8100$ & 4173 & 25 & $1700-10300$ & 4290 & 111 \\
\hline S.G.O.T. (IU) & $18-75$ & 33.6 & 26 & $8-120$ & 33.5 & 129 \\
\hline S.G.P.T. (IU) & $5-54$ & 23.3 & 26 & $5-113$ & 34 & 128 \\
\hline $\begin{array}{l}\text { Alk. phosphat. } \\
\text { (BU) }\end{array}$ & $1.5-10.5$ & 3.80 & 22 & $1-10.7$ & 3.80 & 128 \\
\hline $\begin{array}{l}\text { Blood fibrinogen } \\
\mathrm{mg} / 100 \mathrm{ml}\end{array}$ & $200-540$ & 351 & 18 & $180-650$ & 320 & 128 \\
\hline
\end{tabular}

B. The mean value of blood urea was initially $40.6 \mathrm{mg} / 100 \mathrm{ml}$ and under treatment it remained between 37 and $44 \mathrm{mg} / 100 \mathrm{ml}$, the mean being 41 $\mathrm{mg} / 100 \mathrm{ml}$ (138 estimations).

C. Blood creatinine levels, which were measured in a few cases, remained stable, even when they were high initially, in particular in the two cases mentioned. above.

D. Blood uric acid levels, which were initially high in one quarter of the patients (mean value $5.46 \mathrm{mg} / 100 \mathrm{ml}$ ) underwent non-homogeneous variations around the mean level calculated at $6.04 \mathrm{mg} / 100$ $\mathrm{ml}$ (127 estimations) during treatment. good.

4c) Haematological toleration of glipizide was also slight drop during the first four months of treatment, but after the 5th month mean values were higher than the initial values.

4d) Liver function tests.

A. Serum glutamic oxalacetic transaminase levels, which were initially abnormal in six cases with a mean value of $33.6 \mathrm{U}$., oscillated during treatment around a mean value of 33.5 U. (129 estimations). Thus, pre- and post-treatment values were absolutely identical.

B. Glutamic pyruvic transaminase levels, which were initially abnormal in four patients, with a mean of $23.3 \mathrm{U}$., rose to a mean value of $34 \mathrm{U}$. during treatment (128 measurements). This difference is significant $(p<0.05)$. In fact, during the second 
month of treatment, a rise in SGPT levels was recorded in 11 cases (exceeding $40 \mathrm{U}$. in only 2 cases and later remaining unchanged). One patient with active post-icteric chronic hepatitis for the past five years initially showed a rise of SGPT level from 40 to $113 \mathrm{U}$. and of SGOT level from 40 to $80 \mathrm{U}$. with $2 \frac{1}{2} \mathrm{mg}$ of glipizide daily. But these levels later returned to normal during treatment, and liver biopsies performed during the 4th month showed lesions indicating that the antidiabetic sulphonamide was probably not responsible.

C. Alkaline phosphatase levels were perfectly stable under glipizide: the mean level was 3.80 Bod. $\mathrm{U}$. before and during treatment (128 controls).

D. Blood fibrinogen levels remained unchanged under glipizide (128 titrations), the mean value before treatment being $351 \mathrm{mg} / 100 \mathrm{ml}$, and $320 \mathrm{mg} / 100 \mathrm{ml}$ during treatment $(p>0.05)$.

E. As seen above, blood cholesterol levels remained stable.

F. No drop in blood prothrombin level was noted during treatment with glipizide. One of our patients, however, (prothrombin level 34 to $36 \%$ ) who had been stabilized for the past 6 years following a myocardial infaretion with $125 \mathrm{mg}$ of phenylidanedione daily, suffered severe intestinal hemorrhage thirtyfour days after beginning treatment with $5 \mathrm{mg}$ of glipizide daily (substituted for $1000 \mathrm{mg}$ of glybutamide). Investigations revealed a drop in prothrombin level to $10 \%$. After discontinuation of the anticoagulant, later measurements showed a prothrombin level of $100 \%$ with continuation of glipizide.

\section{Discussion and Conclusions}

Treatment with glipizide for an average of seven months in our 35 patients with non insulin-dependent diabetes confirmed the hypoglycaemic properties of this new sulphonamide in small doses. These properties were demonstrated by experimental investigations and were later confirmed by the first clinical trial performed by Italian authors. In one third of the cases the patients reported subjective improvement and there was a regular decrease of both mean and maximal blood sugar levels in the majority of our patients (Fig. 1). These findings are all the more significant when one considers that most of the patients were aged, had degenerative complications or associated disorders in $86 \%$ of cases and were obese in one third of cases. Eighty per cent of the patients had had diabetes for more than 5 years and $38 \%$ for more than ten years, usually treated by other sulphonamides. During the second and third trimesters of treatment, after careful and gradual adjustment of dosage, the proportion of well stabilized diabetics increased appreciably (from $11 \%$ before glipizide to $39 \%$ with glipizide), while that of poorly controlled cases diminished markedly (from $40 \%$ to $23 \%$ respectively).
In only one newly treated case was it necessary to add secondarily $200 \mathrm{mg}$ of phenformin daily to the $15 \mathrm{mg}$ of glipizide in order to obtain better control.

These results are comparable to those obtained by Parodi [18] with lower doses but in younger patients who had not been previously treated. They are also similar to those of Marigo et al. [4] in patients of comparable age but with a higher mean dosage (141/2 mg/daily) substituted for glycyclamide or tolbutamide. None of our patients had become resistant to sulphonamides before the beginning of treatment with glipizide and we are therefore unable to confirm that the latter is capable of exerting action in patients who have become resistant to sulphonylureas, in particular to glibenclamide, as Parodi claims. Unlike this author, we do not have any experience with the possible benefit which may be expected from the association of glipizide and insulin, which would permit a reduction of dosage. On the other hand, with glipizide we obtained the same benefit that can be expected from associating a biguanide with a sulphonamide, i.e. economy of dosage of the latter, thus preventing hypoglycaemic incidents which are to be particularly feared with these "second generation" antidiabetic sulphonamides.

It is with this fear in mind that initial dose titration was and should be particularly careful and gradual and dosage should only be increased little by little in accordance with clinical and biological findings. This point should be emphasized.

In equivalent doses, glipizide appears as active as glibenclamide and more active than glisoxepide $[9,10]$. With some "first generation" sulphonamides, the correlation appears to be one $5 \mathrm{mg}$ tablet of glipizide for at least 2 tablets of glybutamide $(=1000 \mathrm{mg}$ ), chlorpropamide $(=500 \mathrm{mg})$ or glycodiazine $(=1000$ $\mathrm{mg}$ ); Marigo et al. [14] noted that $5 \mathrm{mg}$ of glipizide were equivalent to $500 \mathrm{mg}$ of tolbutamide or to $500 \mathrm{mg}$ or more of glycyclamide.

Care in the management of treatment and in the adjustment of dosage is justified, particularly when dealing with the type of high risk patients we had in our study. The frequency of minor hypoglycaemic incidents, necessitating the division of daily dosage into two administrations (morning and midday) or its reduction in the case of biologically confirmed over-correction, was not negligible in our series of patients. Late morning hunger or weakness may be felt by the patient even after taking only $21 / 2 \mathrm{mg}$ of glipizide at breakfast, if the carbohydrate content of the latter is insufficient. Timely redistribution of carbohydrates over the three meals may prevent these phenomena.

A special characteristic of our group of patients is that quite a large proportion of them, i.e. eight, had some degree of renal insufficiency. The problem of sulphonylurea treatment in diabetic patients with damaged renal function has been considered by several investigators. Accumulation in the circulation of 
these substances or their metabolites has been demonstrated in patients with severe, and even with a moderate, decrease in the glomerular filtration rate. These patients are prone to hypoglycaemic attacks for several reasons, such as decrease of insulin catabolism in the kidney, poor homeostatic mechanisms and last but not least, the accumulation of the sulphonylureas, either as unchanged drug or as active metabolites in patients receiving them. As far as glipizide is concerned, we know from the metabolic studies performed with this drug $[7,21]$ that it is metabolized in the liver into 4 metabolites of which only 2 are present in significant amounts. Both are almost devoid of hypoglycaemic activity and $80 \%$ of these metabolites are eliminated by the kidneys. Fabre, Balant and Zahnd [6] have recently shown the extent to which the excretion of these substances depends on kidney function. Using $\mathrm{C}^{\mathbf{1 4}}$-labelled glipizide $(5 \mathrm{mg}$ I.V.) these authors demonstrated that the half-life of total radioactivity ( $=$ unchanged drug + metabolites), as measured by the method used, rises from $31 / 2 \mathrm{~h}$ in patients with normal kidneys to $6 \mathrm{~h}$ when the endogenous creatinine clearance falls to $30 \mathrm{ml} / \mathrm{min}$ and to $12 \mathrm{~h}$ when creatinine clearance is $10 \mathrm{ml} / \mathrm{min}$; the renal excretion is reduced from $75 \%$ in $48 \mathrm{~h}$ to $30 \%$ when the kidney function is reduced by threequarters. The same authors have, however, demonstrated that even in severe renal insufficiency the disappearance rate of glipizide itself, i.e. the unchanged drug, is not significantly reduced in comparison with normal subjects, but that the prolonged "half-life" is due to the accumulation in the plasma of the metabolites of the sulfonylurea. As the two major metabolites are virtually devoid of any hypoglycaemic activity, it is unlikely that hypoglycaemic attacks could occur through accumulation of unchanged drug or its metabolites except in severe renal insufficiency, where the glomerular filtration rate is lower than $30 \mathrm{ml} / \mathrm{min}$ (reduction of renal function by more than $75 \%$ ). There is, however, one circumstance where such an incident is more likely i.e. when the impairment of renal function is associated with reduced hepatic function. When both kidney and liver are impaired, metabolism of the drug is slower and the unchanged active substance will accumulate. This was probably the sequence of events in our two patients who experienced severe hypoglycaemia during glipizide treatment. Both had renal insufficiency and abnormal hepatic function tests. In the light of our experience, we would like to recommend rules for glipizide, similar to those previously laid down for the other sulphonylureas. Its use should be avoided in the presence of severe renal insufficiency where the kidney function is reduced by $75 \%$ or more, while in moderate insufficiency (reduction by $50-$ $75 \%$ ) special attention should be given to hepatic function. This should prevent the occurrence of severe hypoglycaemia which has become more common over the past few years $[3,4,10,11,12,16,17,21,22]$. The absence of warning symptoms before the attack is common, and one of our patients illustrates this fact. If high potency sulphonylureas are to be used in such patients, precise rules concerning dosage in relation to the kidney's excretory capacity, should be specified and followed [5, 20].

We did not note other interference with the hypoglycaemic action of glipizide. However, our one and only observation of a diabetic on anticoagulants, prescribed before antidiabetic treatment, suggests that the usual rule of enhancement of anticoagulant action by hypoglycaemic sulphonamides [24] applies to glipizide.

On the basis of our 35 observations, we may conclude that glipizide is a potent hypoglycaemic drug capable of appreciably improving glycaemia previously obtained with other sulphonamides in type I diabetes. Its potency necessitates careful and gradual adaptation of dosage. No toxic effects were observed except for hypoglycaemia as the result of over-dosage or accumulation in the event of renal deficiency, combined with hepatic dysfunction, or in marked renal insufficiency.

We would like to express our thanks to Pfizer Laboratories for having made available the drug necessary for this study.

\section{References}

1. Ambrogi, V., Bloch, K., Daturi, S., Griggi, P., Logemann, W., Parenti, M. A., Rabini, T., Tommasini, R. New oral antidiabetic drugs. Arzneimittelforseh. 21, $200-208$ (1971).

2. Ambrogi, V., Bloch, K., Daturi, S., Griggi, P., Logemann, W., Mandelli, V., Parenti, A., Rabini, T., Usardi, M.M., Tommasini, R.: Pharmacological study of a new oral antidiabetic: N-(4-( $\beta-(5$-methylpyrazine 2-carboxamido)-ethyl)-benzenesulfonyl)- $\mathrm{N}^{\prime}$-cyclohexylurea or K 4024. Arzneimittelforsch. 21, 208-215 (1971)

3. Berger, W.: 88 schwere Hypoglykämiezwischenfälle unter der Behandlung mit Sulfonyl-Harnstoffen. Resultate einer gesamtschweizerischen Umfrage in den Jahren 1968 und 1969. Schweiz. med. Wschr. 101, $1013-1022(1971)$

4. Berger, W., Spring, P.: Veränderung der Pharmakokinetik oraler Antidiabetika durch medikamentöse Interferenz und Niereninsuffizienz. Dtsch. med. Wschr. 95, 2525-2527 (1970)

5. Fabre, J.: Comment prescrire les médicaments en présence de fonctions rénales déficientes? Tables d'adaptation posologique. Schweiz. med. Wschr. 102, $251-256(1972)$

6. Fabre, J., Balant, L., Zahnd, G.: Influence de fonctions rénales déficientes sur le comportement de la glipizide (sulfonylurée hypoglycémiante) et de ses métabolites. Montpellier: C.-R. Soc. Nóphrologie, 1972

7. Fuccella, L. M., Tamassia, V., Valzelli, G.: Metabolism and kinetics of the hypoglycaemic agent glipizide in man - Comparison with glibenclamide. J. clin. Pharmacol. (In press)

8. Greco, A.V., Fedeli, G., Chiranda, G., Lucente, M., Accietto, F., Fenici, R.: Esperienze cliniche sull'azione du un nuovo antidiabetico orale: la glydiazinamide. Minerva med. 62, 2829 -2839, (1971) 
9. Haupt, E., Köberich, W., Bemer, J.: Pharmacodyna mic aspects of tolbutamide, glibenclamide, glibornuride and glisoxepide. Diabetologia 7, 449-460 (1971)

10. Hazard, J., Domart, A.: Deux cas d'hémiplégie révélatrice d'une hypoglycémie sévère provoquée par les sulfamides hypoglycémiants Bull. Soc. Méd. Paris. 116, $473-476$ (1965)

11. Lamotte, M., Segrestaa, J.M., Martin, E., Vilde, J. L. Hypoglycémie mortelle par sulfamide hypoglycémiant chez un patient porteur d'un adénome du cortex surrénal et d'une insuffisance rénale. Sem. Hôp. Paris 41, $2371-2374(1965)$

12. Laroche, Cl., Nenna, A., Cremer, G., Caquet, R.: Hypoglycémies graves chez les diabétiques traités par les sulfamides hypoglycémiants. Bull. Soc. Méd. Paris $116,461-466$ (1965)

13. Loubatieres, A., Mariani, M.M., Ribes, G.: Pharmacologioal study of a now hypoglycaemic sulfonamide, glisoxepid (R.P. 22.410). Diabetologia 8, 29-36 (1972)

14. Marigo, S., Del Novo, G., Bini, P.P., Sacchetti, G.: Pharmacological methods for evaluating a new hypoglycaemic agent in humans: a multiple design. Arzneimittel-Forsch. 21, 215-220 (1971)

15. Masbernard, A., Portal, A.: Le vrai problème du diabète. Essai du gliclazide, molécule originale à propriétés métaboliques et vasculaires. Thérapeutique 48, 569-574 (1972)

16. Montgolfier, R. de, Kressmann, J., Plauchu, M.: Les accidents hypoglycémiques des sulfamides antidiabétiques. Lyon med. 225, 97-108 (1971)
17. Nissen-Druey, C., Berger, W., Huber, F.: Hypoglykämien bei der Anwendung oraler Antidiabetika. Praxis 59, 53-57 (1970)

18. Parodi, F.A.: Pharmacological and clinical evaluation of the activity of a new oral antidiabetic, gly. diazinamide (K 2024). (Unpublished report).

19. Pedrazzi, F., Pisani Ceretti, A., Losi, S., Bommartini, F., Artini, D., Emanueli, A.: Evaluation in hospitalized subjects of a new hypoglycaemic sulfonylurea, glydiazinamide Arzneimittel-Forsch. 21, 220-225 (1971)

20. Reidenberg, M.M.: Renal function and drug action. London: W. B. Saunders Co. 1971

21. Schach von Wittenau, M.: Metabolism of K 2024 (glydiazinamide) in man, dog, rat and mouse. (Unpublished report)

22. Vazquez Rodriguez, J.J., Barreira Tella, P., Ortiz Vazquez, J.: Hipoglicemias por antidiabeticos orales. Rev. clin. esp. 118, 21-30 (1970)

23. Vazquez, A., Moya, G. G., Ricoy, J.R.: Aspectos neurologicos de los comas hipoglicemicos de origen medico por uso de hipoglicemiantes. Rev. clin. esp. 117, 158 $168(1970)$

24. Viars, P., Seebacher, J.: Les interférences médicaw menteuses. Risques thérapeutiques et incompatibilités. Paris: Arnette Edit. 1971

Prof. A. Masbernard

Hopital du Val-de-Grace

277 a, Rue St. Jacques

F-75005 Paris

France 